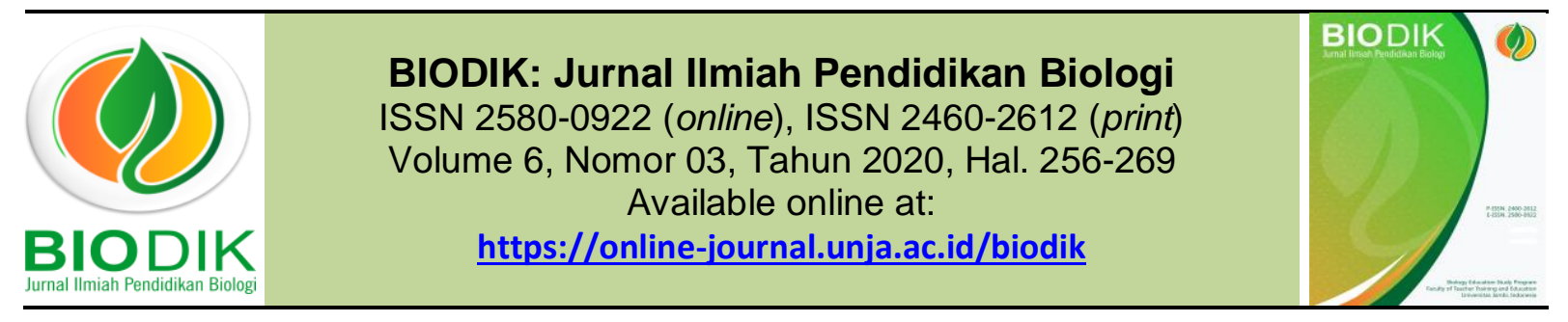

Research Article open Access

\title{
Penggunaan Assesment for Learning Berbasis Comment Only Marking Terhadap Hasil Belajar Kognitif Siswa
}

\author{
(Use of Comment Only Marking Based Assessment for Learning on Student Cognitive \\ Learning Outcomes)
}

Hana Nurul Karimah*, Sistiana Windyariani, Himatul Aliyah

Pendidikan Biologi, FKIP, Universitas Muhammadiyah Sukabumi Jalan R. Syamsudin SH No. 50 Kec. Cikole Kota Sukabumi

Corresponding Author : hananurulkarimahdz@gmail.com

\begin{tabular}{|c|c|}
\hline Informasi Artikel & ABSTRACT \\
\hline $\begin{array}{l}\text { Submit: } 10-06-2020 \\
\text { Diterima: } 17-07-2020 \\
\text { Dipublikasikan: } 01-09-2020\end{array}$ & $\begin{array}{l}\text { Assessment for learning based on comment only marking is an } \\
\text { assessment not only of scores, but students get follow-up from } \\
\text { comments given as feedback. The study aims to determine the effect } \\
\text { of assessment for learning based on comment only marking on the } \\
\text { cognitive learning outcomes of class XI students of State Senior High } \\
\text { School Sukabumi Regency on the material of the regulatory system. } \\
\text { This study used a pre-experimental method and used a one-group } \\
\text { pretest-postest design. Samples were taken by purposive sampling } \\
\text { technique, amounting to } 36 \text { students. The research instrument was in } \\
\text { the form of cognitive test questions and student response } \\
\text { questionnaires. The test questions used were cognitive tests based } \\
\text { on revised Bloom's taxonomy consisting of } 30 \text { multiple choice } \\
\text { questions. The student response questionnaire used was } 30 \\
\text { statements with negative and positive types of statements. Data } \\
\text { analysis refers to the provisions of the cognitive ability category. The } \\
\text { data obtained were as many as } 86 \% \text { of students scored very good } \\
\text { cognitive learning outcomes, 92\% of students were complete in } \\
\text { learning and } 83 \% \text { of students gave positive responses to the use of } \\
\text { comment only marking-based assessment for learning. The results of } \\
\text { this study indicate an influence on the use of comment only marking } \\
\text { based assessment for learning on the cognitive learning outcomes of } \\
\text { high school students on the human regulatory system material. } \\
\text { Keywords: Assessment for Learning, Comment Only Marking, } \\
\text { Cognitive Learning Outcomes. }\end{array}$ \\
\hline Penerbit & ABSTRAK \\
\hline $\begin{array}{l}\text { Program Studi Pendidikan } \\
\text { Biologi, Fakultas Keguruan dan } \\
\text { Ilmu Pendidikan, Universitas } \\
\text { Jambi }\end{array}$ & $\begin{array}{l}\text { Assessment for learning berbasis comment only marking merupakan } \\
\text { penilaian tidak hanya skor namun siswa mendapatkan tindak lanjut } \\
\text { dari komentar yang diberikan sebagai feedback. Penelitian bertujuan } \\
\text { untuk mengetahui pengaruh assesment for learning berbasis } \\
\text { comment only marking terhadap hasil belajar kognitif siswa kelas XI } \\
\text { Sekolah Menengah Atas Negeri Kabupaten Sukabumi pada materi } \\
\text { sistem regulasi. Penelitian ini menggunakan metode pre- } \\
\text { eksperimental dan menggunakan one-group pretest-postest design. } \\
\text { Sampel diambil dengan teknik purposive sampling berjumlah } 36 \\
\text { siswa. Instrumen penelitian ini berupa soal tes kognitif dan angket } \\
\text { respon siswa. Soal tes yang digunakan yaitu tes kognitif berdasarkan } \\
\text { taksonomi Bloom revisi terdiri dari } 30 \text { soal pilihan ganda. Angket } \\
\text { respon siswa yang digunakan berjumlah } 30 \text { pernyataan dengan jenis }\end{array}$ \\
\hline
\end{tabular}


pernyataan negative dan positif. Analisis data mengacu pada ketentuan kategori kemampuan kognitif. Data yang diperoleh yaitu sebanyak $86 \%$ siswa mendapatkan nilai hasil belajar kognitif dengan kategori sangat baik, 92\% siswa tuntas dalam pembelajaran dan $83 \%$ siswa memberikan respon positif terhadap penggunaan assessment for learning berbasis comment only marking. Hasil penelitian ini menunjukkan adanya pengaruh pada penggunaan assesment for learning berbasis comment only marking terhadap hasil belajar kognitif siswa SMA pada materi sistem regulasi manusia.

Katakunci: Assessment for Learning, Comment Only Marking, Hasil Belajar Kognitif.

This BIODIK : Jurnal IImiah Pendidikan Biologi is licensed under a CC BY-NC-SA (Creative Commons Attribution-ShareAlike 4.0 International License)

\section{PENDAHULUAN}

Kemampuan kognitif merupakan kemampuan berupa perilaku yang memfokuskan aspek intelektual, seperti pengetahuan, dan keterampilan berfikir (Bloom et al., 1956). Keterampilan berfikir, khususnya pada kelanjutan kognitif merupakan salah satu sentral atensi pendidikan matematika dan sains (Erny et al., 2017). Dalam Pasal 1 (1) Undang-undang No. 20 Tahun 2003 tentang Sistem Pendidikan Nasional: Pendidikan adalah usaha sadar dan terencana untuk mewujudkan suasana belajar dan proses pembelajaran agar siswa secara aktif mengembangkan potensi dirinya untuk memiliki kekuatan spiritual keagamaan, pengendalian diri, kepribadian, kecerdasan, akhlak mulia serta keterampilan yang diperlukan dirinya, masyarakat, bangsa dan negara (Anonim, 2003). Salah satu hal yang harus diperhatikan pada Undang-Undang tersebut yaitu pembelajaran dilakukan dengan tujuan kecerdasan dan siswa harus menggalinya dengan pengembangan potensi yang dilakukan, hal tersebut berarti bahwa pendidikan harus berorientasi pada siswa untuk mengembangkan serta mencapai kemampuan kognitifnya. Kemampuan kognitif didasari oleh aspek yang mencakup kemampuan intelektual sederhana, yaitu mengingat, hingga kemampuan menggabungkan gagasan, prosedur, dan ide yang dipelajari untuk menuntut siswa dalam memecahkan masalah. Hal tersebut selaras dengan Badan Standar Nasional Pendidikan (BSNP) yang mengemukakan bahwa proses pembelajaran diharapkan dapat menjadi sarana bagi siswa untuk memecahkan masalah dengan melakukan aplikasi di kehidupan sehari-hari dari pengetahuan yang didapat (Anonim, 2017).

Persoalan di dunia pendidikan yang dihadapi saat ini adalah proses pembelajaran yang lemah, seperti kurangnya dorongan terhadap siswa untuk mengembangkan kemampuan berfikir, yang berdampak terhadap peningkatan hasil belajar yang ditentukan dengan tingkat pencapaian standar minimal (Ali Sadikin et al., 2016; Sanjaya, 2011). Aktivitas selama proses pembelajaran berlangsung merupakan salah satu pengaruh dari baik atau tidaknya peningkatan kemampuan kognitif siswa yang dapat ditinjau dari prestasi atau hasil belajar. Untuk mengetahui berhasil atau tidaknya suatu proses pembelajaran, maka yang harus dilakukan 
seorang guru yaitu melakukan asesmen atau penilaian agar adanya perbaikan pembelajaran (A Sadikin, 2018; Uno, 2011).

Perbaikan pembelajaran harus dilakukan agar siswa dapat meningkatkan penguasaan pengetahuan yang dapat dilakukan dengan proses menggali serta menerjemahkan fakta yang mampu membantu guru dan siswa untuk memutuskan posisi mereka dalam pembelajaran, capaian yang dijadikan acuan, serta alternatif paling efektif untuk mencapainya (Hamalik, 2015; Sulastiyo, 2019). Sejalan dengan Black \& William yang mengemukakan bahwa asesmen dalam pendidikan merupakan aktivitas interpretasi serta analisis data atau informasi yang telah dikumpulkan berkaitan dengan siswa maupun lingkungannya dengan tujuan memperoleh gambaran bagaimana keadaan siswa sebagai bahan untuk guru dalam memahami siswa serta untuk menentukkan tindak lanjut terhadap siswa berupa tindakan pembelajaran maupun layanan bimbingan dan konseling berdasarkan kebutuhan yang disesuaikan dengan siswa (Black et al., 2004).

Assesment atau penilaian sangat penting karena dapat mengemukakan informasi hasil belajar secara menyeluruh dan berkesinambungan dengan proses belajar siswa yang dapat dijadikan acuan untuk dilakukannya evaluasi pembelajaran dan pengembangan kompetensi siswa yang sudah maupun belum tercapai. Assesmet dapat menjadi suatu instrumen yang bisa mengungkap keinginan dan harapan dalam sistem pendidikan secara keseluruhan. Hal ini sejalan dengan National Research Council melalui National Science Education Standard, yang mengemukakan bahwa asesmen adalah sebuah sistematika feedback utama dalam mekanisme pendidikan sains (Council, 2000). Asesmen yang ditekankan pada kurikulum 2013 salah satunya yaitu asesmen autentik. Adapun karakteristik yang dimiliki oleh asesmen autentik yaitu berupa assessment of learning serta assessment for learning. Assesment for learning sering dikenal juga dengan asesmen sumatif. Assesment of learning merupakan asesmen yang digunakan hanya untuk mengukur ketercapaian indikator pembelajaran dan menentukan kemampuan siswa dari hasil akhir proses pembelajaran yang didapatkan. Menurut (Kirbani, 2013) mengatakan bahwa assessment of learning tidak memberikan usaha perbaikan pembelajaran karena siswa hanya mendapatkan skor sehingga kemampuan kognitif siswa akan terlihat hanya di akhir pembelajaran dan sangat sedikit dalam memberikan feedback dalam proses pembelajaran yang akan didapatkan oleh siswa. Hingga saat ini, pendidik di Indonesia pada umumnya menggunakan assessment of learning, yaitu asesmen yang diberikan secara berkala untuk menentukan pemahaman siswa dari topik pada titik tertentu dalam waktu dan berkaitan dengan standar isi. Asesmen tersebut digunakan tanpa memberikan dampak secara langsung pada pembelajaran dan tidak dapat melihat kemajuan kemampuan kognitif siswa secara periodik, maka sulit terwujudnya hasil belajar siswa yang diharapkan sesuai dengan kompetensi dasar yang ada dalam kurikulum. Pemberian assessment of learning umumnya berupa skor serta tiada tindak lanjut berdasarkan penilaian yang diberikan tersebut (Black et al., 2004). 
Biologi adalah salah satu mata pelajaran yang memiliki pengaruh sangat tinggi terhadap kompetensi ilmu pengetahuan dan teknologi dengan kedudukan penting di dalam dunia pendidikan. Pembelajaran biologi identik dengan mata pelajaran dengan materi berupa konsep yang sulit dipahami siswa. Pemahaman siswa akan didapatkan jika guru dan siswa bisa saling berkomunikasi dengan baik serta saling memberikan feedback dalam penilaian yang memberikan keterlanjutan pada proses belajar siswa yang menjadikan peningkatan pada hasil belajar kognitif siswa. Berdasarkan observasi, nilai kognitif rata-rata biologi siswa pada kelas XI IPA $78 \%$ belum tuntas atau mencapai $\mathrm{KKM}$ dan hanya $22 \%$ siswa dengan $\mathrm{KKM}$ yang tercapai.

Dalam pelaksanaan pembelajaran didapat beberapa masalah yang dihadapi, diantaranya siswa tidak mengetahui kekurangan dan kelebihan dari pengetahuan yang mereka miliki. Hal tersebut karena asesmen yang diberikan guru didominasi oleh assessment of learning yaitu penilaian yang diberikan hanya berupa skor dan tidak memberikan feedback. Dengan demikian diperlukan suatu strategi penilaian untuk meningkatkan hasil belajar kognitif siswa, yaitu dengan penilaian formatif yang disebut juga dengan Assesment for Learning.

Assesment for Learning dirasa dapat digunakan selama proses pembelajaran untuk meningkatkan hasil belajar kognitif siswa. Assessment for learning merupakan assessment yang terjadi selama proses pembelajaran dan bukan pada akhir. Assessment for learning menggeser penekanan dari penilaian sumatif ke penilaian formatif, mulai dari membuat penilaian hingga membuat deskripsi yang dapat digunakan untuk melayani tahap pembelajaran selanjutnya. Pada penggunaan Assessment for learning, guru mengumpulkan berbagai data sehingga mereka dapat memodifikasi pekerjaan pembelajaran untuk siswa, seperti melalui penilaian pada tugas yang diberikan guru terhadap siswa. Pada Assessment for learning guru menggunakan pengetahuan pribadinya untuk menilai siswa dan menilai pemahaman mereka tentang konteks penilaian dan target kurikulum untuk mengidentidikasi kebutuhan pembelajaran tertentu.

Assessment for Learning (AfL) dapat sangat membantu terhadap peningkatan kemampuan belajar siswa. Berdasarkan (Black et al., 2004) AfL terbukti dalam peningkatan hasil belajar akademik. Menurut pendapat (Ohlsen, 2007) assesment for learning dilakukan oleh guru untuk menentukan strategi atau diferensiasi apa yang dapat dilakukan dengan proses pengumpulan data atau informasi yang berkelanjutan dan menafsirkan bukti tentang hasil belajar siswa untuk tujuan perbaikan dengan menentukaan bagaimana siswa paham terhadap konsep materi pembelajaran dan bagaimana cara terbaik untuk memperbaiki materi yang belum dipahaminya.

Menurut (Black et al., 2004) mengidentifikasi strategi $A f L$ menjadi 4 elemen yaitu Use Of Question (UOQ), Comment Only Marking (COM), Self/Peer Assesment (SPA dan Formative use of Summative (FUSA). Dalam penelitian Eremina, et.al (2016) penggunaan Assesment for Learning (AfL) berbasis Comment Only Marking (COM) memiliki efek paling signifikan pada peningkatan hasil belajar kognitif siswa 
pada mata pelajaran biologi dibandingkan dengan penggunaan $A f L$ berbasis lainnya. Dengan $A f L$ berbasis COM guru bukan saja memberikan penilaian berupa nilai maupun skor, namun pemberian komentar dilakukan guru pada pekerjaan siswa. Pemberian Comment Only Marking dari guru diharapkan mampu mengarahkan siswa agar mengetahui apa saja langkah yang harus diusahalam untuk merekonstruksi kemampuan kognitif siswa (Koh et al., 2010). Komentar yang diberikan berfokus pada tugas, bukan komentar yang berfokus pada ego agar feedback yang siswa terima efektif. Penelitian (O'Mahoney \& Heinz, 2016) di Irlandia juga mengungkapkan bahwa AfL berbasis COM berdampak positif digunakan pada penilaian di kelas. Menurut (Black et al., 2004) dengan AfL berbasisis COM guru dapat meninjau kemajuan pengetahuan siswa melalui berbagai bentuk penilaian formatif berupa tugas, kuis, presentasi, dan lain-lain.

Adapun materi pada penelitian ini adalah sistem regulasi manusia yang merupakan salah satu materi semester genap di kelas XI IPA yang siswa pelajari. Materi ini erat kaitannya dengan keseharian dalam hidup juga bersifat kontekstual sehingga siswa dituntut untuk memiliki penguasaan konsep yang baik. Dengan assessment for learning berbasis comment only marking siswa mendapat banyak kesempatan untuk merefleksi serta mengevaluasi pemahaman mereka mengenai materi tersebut karena siswa mendapatkan umpan balik berupa komentar dari guru pada hasil pekerjaan siswa yang dapat mendorong siswa berfikir mengenai apa yang harus mereka perbaiki dan mengubah pekejaan mereka. Dengan begitu siswa mendapat motivasi untuk bertindak agar kemampuan belajar siswa lebih baik sehingga dapat meningkatkan kemampuan kognitifnya.

\section{METODE PENELITIAN}

Metode penelitian yang digunakan yaitu pra-eksperimen (Pre-Eksperimental) dengan rancangan desain One-Group Pretest-Postest Design. Prosedur penelitian meliputi 3 tahap yang terdiri dari pemberian pretest, pemberian perlakuan (assessment for learning berbasis comment only marking), dan pemberian posttest.

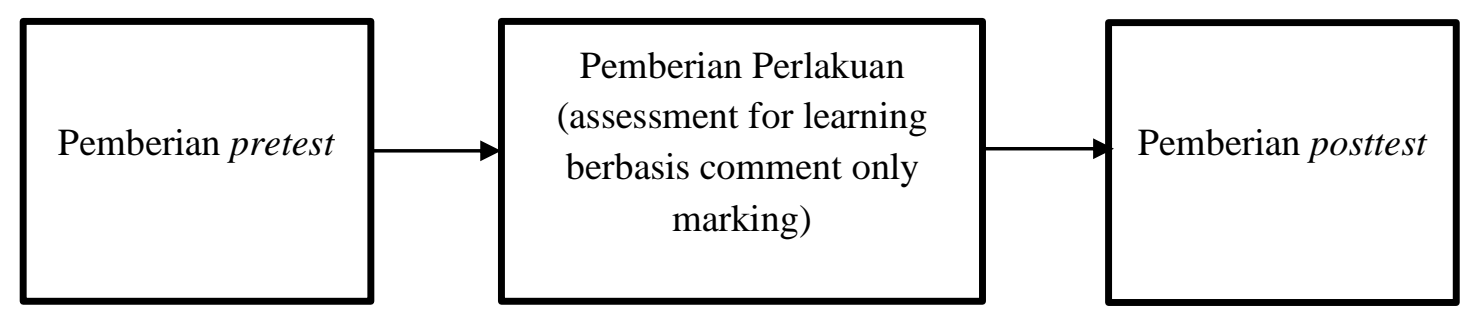

\section{Gambar 1: Prosedur Penelitian}

Adapun populasi dalam penelitian ini yaitu seluruh siswa kelas XI SMAN 1 Cisaat tahun ajaran 2019/2020 dengan total jumlah 216 siswa yang merupakan cakupan dari 6 kelas yaitu kelas XI IPA 1 sampai XI IPA 6. Sampel dalam penelitian ini yaitu kelas XI IPA 3 yang terdiri dari 36 siswa. Pengambilan sampel dilakukan 
dengan teknik purposive sampling yang merupakan salah satu teknik non random sampling. Sampel ditentukan berdasarkan ciri-ciri khusus yang dimiliki dan sesuai dengan tujuan penelitian dan pertimbangan tertentu. Penelitian dilakukan pada minggu ke-2 dan ke-3 di bulan April 2020.

Penelitian ini menggunakan instrumen untuk mengumpulkan data dengan bentuk berupa tes dan angket respon siswa. Tes yang digunakan yaitu tes kognitif berdasarkan taksonomi Bloom revisi dengan indikator C1 (mengingat), C2 (memahami), C3 (mengaplikasikan), C4 (menganalisis), C5 (mengevaluasi), dan C6 (mencipta). Tes kognitif yang diberikan terdiri dari 30 soal berbentuk pilihan ganda (multiple choice) dengan pilihan a, b, c, d, dan e sebagai pilihan alternative jawaban. Angket respon siswa yang digunakan berjumlah 30 pernyataan dengan jenis pernyataan negative dan positif untuk mengetahui tanggapan serta pandangan siswa terhadap penggunaan Assesment for Learning berbasis Comment Only Marking yang dilakukan selama pembelajaran. Jawaban angket tersebut dikelompokkan dengan skala Sangat Setuju (SS), Setuju (S), Tidak Setuju (TS), dan Sangat Tidak Setuju (STS) (Sugiyono, 2015).

Data dikumpulkan dengan teknik pemberian tes kogntif dan angket. Tes kognitif diberikan berupa pretest dan posttest dengan soal serupa yang bersifat objektif. Sedangkan angket respon siswa yang diberikan dalam bentuk tanggapan siswa tentang penggunaan Assesment for Learning dalam pembelajaran. Data yang telah didapat diananilisis secara deskriptif dan inferensial. Adapun kategori kemampuan kognitif menurut Kemendikbud tahun 2013 (Anonim, 2013) disajikan pada tabel 1.

Tabel 1. Kategori kemampuan kognitif

\begin{tabular}{ll}
\hline Nilai & Kategori \\
\cline { 1 - 2 } Skala $\mathbf{0 - 1 0 0}$ & \\
\hline $81-85$ & Sangat baik \\
$66-80$ & Baik \\
$51-65$ & Cukup \\
$46-50$ & Kurang \\
\hline
\end{tabular}

\section{HASIL DAN PEMBAHASAN}

Penelitian ini mengukur hasil belajar kognitif siswa berdasarkan tingkatan pada taksonomi Bloom revisi, karena taksonomi Bloom revisi telah disesuaikan dengan tuntutan abad ke-21 dan telah dipertimbangkan sebagai jangkauan yang lebih luas dari bermacam-macam faktor yang berpengaruh terhadap kegiatan pembelajaran. Taksonomi Bloom revisi juga merupakan perbaikan dari taksonomi lama, sehingga dapat dikatakan bahwa taksonomi revisi bersifat lebih fleksibel dan telah disesuaikan dengan kemajuan zaman (Krathwohl, 2002). Data nilai rata-rata pretest dan posttest siswa yang disajikan pada gambar 2 . 


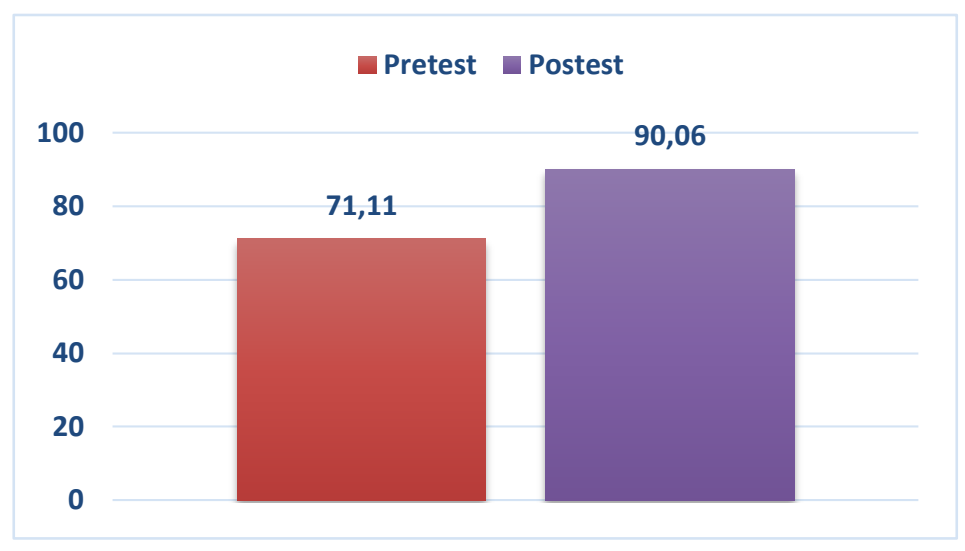

Gambar 2. Grafik Nilai Rata-Rata Pretest dan Postest Siswa

Dari data nilai yang didapatkan, kemudian ditafsirkan dan dikelompokkan sehingga menghasilkan persentase jumlah siswa berdasarkan kategori kemampuan kognitif siswa pada materi sistem regulasi manusia yang disajikan pada gambar 3 .

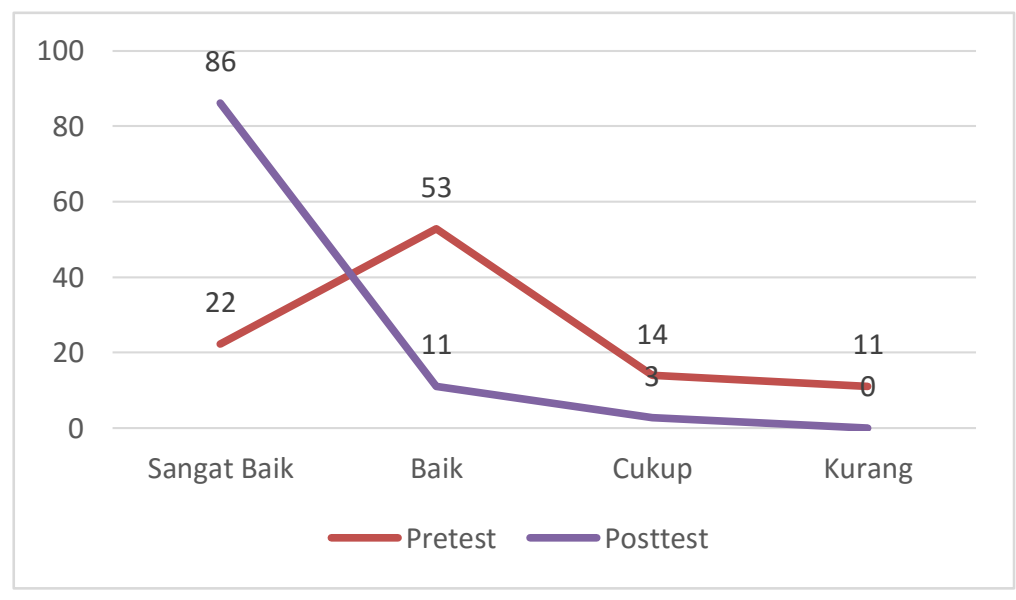

Gambar 3. Persentase (\%) Jumlah Siswa Berdasarkan Kategori Kemampuan Kognitif Siswa

Penelitian penggunaan AfL berbasis COM terhadap hasil belajar kognitif memperoleh temuan bahwa adanya peningkatan hasil belajar kognitif siswa ditinjau dari nilai rata-rata pretest yang didapatkan sebesar 71,11 dan nilai rata-rata posttest yang didapatkan sebesar 90,06. Peningkatan tersebut dapat dilihat dengan rinci berdasarkan kategori kemampuan kognitif yang dikemukakan Kemendikbud (2013). Pada saat pretest $11 \%$ dari 36 siswa yaitu 4 siswa memperoleh nilai $46-50$ dengan kategori kurang. Sejumlah 5 siswa (14\%) dari 36 siswa mendapatkan nilai 51-65 dengan kategori cukup. Sebanyak 53\% siswa atau 19 siswa memperoleh nilai 66-80 termasuk kategori baik, dan $22 \%$ dari 36 siswa yaitu 8 siswa memperoleh nilai $>80$ dengan kategori. Pada saat posttest tidak ada satu siswa pun yang mendapatkan nilai 46-50 yang berarti persentase siswa dengan kategori kurang yaitu $0 \%$. Kemampuan kognitif dengan kategori cukup yaitu yang ditemukan pada 3 siswa atau $3 \%$ siswa dengan nilai $51-65$. Sejumlah 4 siswa atau $11 \%$ siswa memperoleh nilai 
66-80 dengan kategori baik, dan sebanyak 31 siswa memperoleh nilai 81-100, maka $86 \%$ siswa dengan kategori kemampuan kognitif sangat baik. Dengan hasil tersebut, jumlah siswa yang memperoleh nilai kemampuan kognitif dengan kategori sangat baik jauh lebih tinggi didapatkan pada saat posttest dibandingkan pada saat pretest. Penelitian ini juga membuktikan bahwa setelah digunakan assessment for learning berbasis comment only marking pada pembelajaran, sebanyak 92\% siswa dinyatakan tuntas KKM jika mendapatkan nilai sama atau lebih dari 78. KKM merupakan salah satu prinsip penilaian berbasis kompentesi yang digunakan sebagai acuan kriteria untuk menentukan ketuntasan belajar siswa (Depdiknas, 2008). Adapun KKM yang ditetapkan merupakan hasil dari musyawarah secara akademis dari guru mata pelajaran dan guru kelas di SMAN 1 Cisaat. Peningkatan hasil belajar kognitif siswa terjadi pada penelitian ini dikarenakan selama dilakukannya penelitian, waktu pembelajaran masih sangat kondusif yaitu pada jam ketiga, siswa pun masih bersemangat dan pembelajaran berjalan efektif sehingga perlakuan yang diberikan guru digunakan dengan baik oleh siswa.Pada penelitian ini, hasil belajar kognitif siswa berdasarkan setiap indikator Taksonomi Bloom revisi mengalami peningkatan. Berikut hasil penelitian ditinjau dari nilai rata-rata pretest dan posttest pada masing-masing indikator.

Tabel 2. Rata-rata nilai Pretest dan Posttest Untuk Setiap Indikator Hasil Belajar Kognitif

\begin{tabular}{|c|c|c|c|c|c|c|}
\hline No & $\begin{array}{l}\text { Indikator } \\
\text { Kognitif }\end{array}$ & Belajar & $\begin{array}{l}\text { Rata-rata } \\
\text { Pretest }\end{array}$ & Posttest & $\mathrm{N}$-gain & Kriteria \\
\hline 1. & Mengingat (C1) & & 74,2 & 88,3 & 0.55 & Sedang \\
\hline 2. & Memahami (C2) & & 68,9 & 92,8 & 0.77 & Tinggi \\
\hline 3. & Mengaplikasikan (C3) & & 75,0 & 88,9 & 0.56 & Sedang \\
\hline 4. & Menganalisis (C4) & & 80,6 & 88,9 & 0.43 & Sedang \\
\hline 5. & Mengevaluasi (C5) & & 55,6 & 88,9 & 0.75 & Tinggi \\
\hline 6. & Mencipta (C6) & & 52,8 & 86,1 & 0.71 & Sedang \\
\hline
\end{tabular}

Berdasarkan tabel di atas, peningkatan nilai rata-rata setiap indikator hasil belajar kognitif menunjukkan bahwa pada indikator $\mathrm{C} 1$ (mengingat) memperoleh nilai rata-rata pretest sebesar 74,2 dan posttest 88,3 dengan n-gain 0,55 . Hal ini disebabkan pada saat posttest siswa telah mengetahui kekurangan mereka pada kemampuan penalaran serta berfikir melalui Comment Only Marking yang diberikan guru sehingga hal tersebut dapat meningkatkan siswa untuk mengingat konsep maupun fakta terkait materi yang telah dipelajari. Pada indikator C2 (memahami) nilai rata-rata pretest sebesar 68,9 dan posttest sebesar 92,8 dengan n-gain 0,77. Peningkatan tertinggi siswa jika dibandingkan dengan indikator lainnya ditemukan pada indikator C2 yang berarti siswa mampu mencari, memperbaiki hingga menemukan suatu pengetahuan secara mandiri. Tercermin dari konsep Comment Only Marking yaitu komentar yang diberikan oleh guru dapat menjadikan siswa menemukan peluang dan ruang untuk lebih fokus dalam memahami setiap materi yang telah diajarkan dan memperbaiki sesuai arahan komentar yang diberikan. Pada indikator C3 (mengaplikasikan) nilai rata-rata pretest sebesar 75,0 dan posttest 88,9 
dengan n-gain 0,56. Peningkatan tersebut terjadi karena Comment Only Marking yang diberikan guru dikaitkan dengan setiap permasalahan yang sinkron dengan kehidupan sehari-hari supaya siswa mampu mengaplikasikan prinsip serta konsep yang didapatkannya pada kondisi baru dalam kesehariannya. Pada indikator C4 (menganalisis) nilai rata-rata pretest sebesar 80,6 dan posttest 88,9 dengan n-gain 0,43 , ini berarti siswa mengalami peningkatan dalam kemampuan menguraikan informasi, menemukan asumsi juga mampu menemukan sebab akibat yang berkaitan dengan materi berdasarkan Comment Only Marking yang didapatkan dari guru. Indikator C5 (mengevaluasi) nilai rata-rata pretest sebesar 55,6 dan posttest 88,9 dengan n-gain 0,75 , ini merupakan peningkatan yang tinggi. Hal tersebut berarti siswa mampu lebih menguasai dalam mengevaluasi informasi berdasarkan Comment Only Marking yang diberikan guru sehingga siswa mampu membuat keputusan serta kebijakan yang lebih baik dari sebelumnya. Pada indikator C6 (menciptakan) nilai rata-rata pretest sebesar 52,8 dan posttest 86,1 dengan n-gain 0,71 . Hal tersebut disebabkan adanya perlakuan yang menarik dari guru sehingga proses belajar siswa pada indikator C6 terjadi peningkatan. Pemberian Assesment for Learning berbasis Comment Only Marking mampu menjadikan materi lebih jelas untuk memperbaiki kelemahan siswa sehingga proses pembelajaran terjadi secara lebih kooperatif dan menghasilkan hasil belajar yang lebih baik.

Peranan Assesment for Learning berbasis Comment Only Marking pada pembelajaran sangat diperlukan untuk mendorong peningkatan kemampuan kognitif karena COM merupakan bentuk dari umpan balik (feedback), feedback yang diperlukan siswa yaitu berupa komentar yang bersifat konstruktif (Ebrahim, 2019). Maka dari itu kalimat Comment Only Marking harus mencakup Medals, Missions and Goals method. Lebih lanjut (Zainul, 2008) mengemukakan bahwa penggunaan Assesment for Learning khususnya pemberian feedback terhadap siswa sangat penting karena guru dapat mengidentifikasi kelemahan siswa meninjau dari hasil belajar kognitif siswa sehingga guru dapat melakukan perbaikan, penyesuaian dan penentuan strategi dengan segera. Dengan AfL berbasis COM, siswa dapat peluang untuk memperbaiki serta mrefleksi kemampuan kognitif mereka mengenai suatu materi, hal tersebut merupakan faktor yang diperlukan dalam hal perbaikan pembelajaran. Hal tersebut sejalan dengan penelitian (Ziman et al., 2007) menjelaskan bahwa pemberian $A f L$ secara umum dapat memberikan motivasi siswa dengan menumbuhkan rasa percaya diri, optimisme serta apresiasi siswa yang dapat membantu meningkatkan kemampuan kognitifnya. Tidak hanya untuk siswa, AfL berbasis COM juga dapat memberikan feedback untuk guru sehingga keduanya sama-sama bertindak berdasarkan feedback untuk meningkatkan proses pembelajaran (Yin et al., 2014). Selain itu, (Gioka, 2010) mengemukakan bahwa komentar/comment yang ditulis guru pada hasil tugas siswa mempunyai fungsi spesifikasi morfen terikat yakni untuk memicu siswa berfikir mengenai apa yang harus mereka perbaiki terhadap kekurangan pengetahuannya.

Respon siswa terhadap penggunaan Assesment for Learning berbasis Comment Only Marking didapatkan melalui angket respon yang diberikan pada 
siswa dengan pernyataan positif dan negatif. Dengan data respon tersebut akan mengemukakan perspektif mereka terhadap penggunaan AfL berbasis COM. Adapun data respon siswa terhadap penggunaan AfL berbasis COM dapat dilihat dalam gambar 4 .

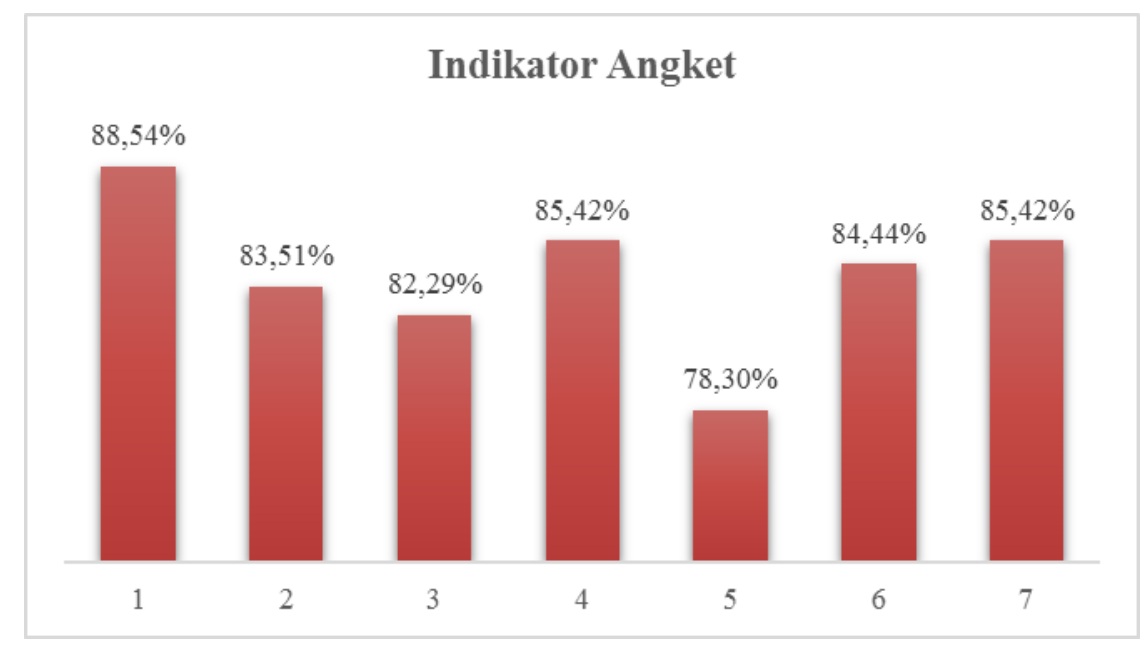

Gambar 4. Persentase Angket Respon Siswa

Keterangan:

Indikator 1 : Ketertarikan siswa mempelajari Biologi

Indikator 2 : Ketertarikan siswa mempelajari Biologi menggunakan AfL berbasis COM

Indikator 3 : Ketekunan siswa menyelesaikan tugas yang diberikan guru

Indikator 4 : Kesukaan siswa mempelajari Biologi

Indikator 5 : Kesukaan siswa mempelajari Biologi menggunakan AfL berbasis COM

Indikator $6:$ Kesungguhan siswa terhadap pengerjaan tugas dari guru

Indikator 7 : Cara guru menyampaikan materi

Berdasarkan diagram tersebut dapat dilihat bahwa pada indikator 1 rata-rata $88,54 \%$ siswa memberikan respon positif terhadap mata pelajaran Biologi, indikator 2 rata-rata $83,51 \%$ siswa memberikan respon positif terhadap pengalaman belajar menggunakan Afl berbasis COM, indikator 3 rata-rata siswa memberikan 82,29\% respon posistif terhadap ketekunan siswa dalam menyelesaikan tugas dari guru, indikator 4 terlihat bawa rata-rata $85,42 \%$ siswa memberikan respon negative terhadap pernyataan yang mengungkapkan ketidaksukaan siswa dalam belajar Biologi, indikator 5 rata-rata $78,30 \%$ siswa memberikan respon negative mengenai ketidaksukaan siswa dalam belajar dengan menggunakan AfL berbasis COM, indikator 6 menunjukkan bahwa rata-rata 84,44\% siswa merespon negative terhadap pernyataan ketidaksungguhan siswa pada tugas yang diberikan guru, dan indikator 7 menunjukan bahwa rata-rata $85,42 \%$ siswa merespon positif terhadap cara guru dalam menyampaikan materi. Adapun persentase respon siswa yang disajikan dalam gambar 5 . 


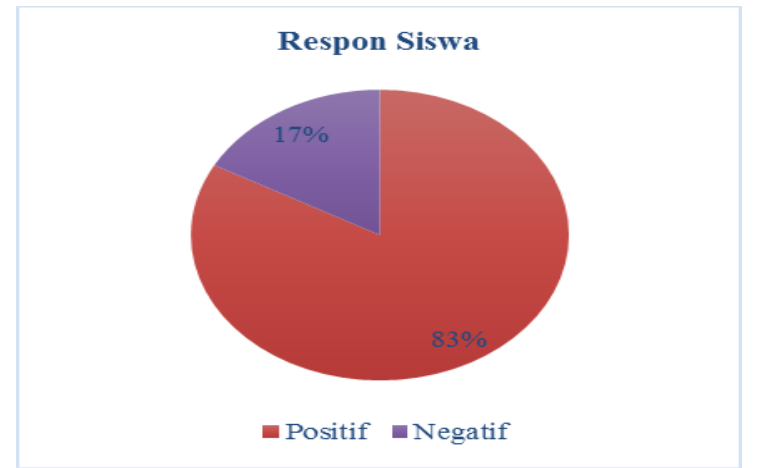

\section{Gambar 5. Persentase Respon Siswa}

Berdasarkan grafik tersebut terihat bahwa 83\% siswa memberikan respon positif dan $17 \%$ siswa memberikan respon negative terhadap pembelajaran menggunakan Assesment for Learning berbasis Comment Only Marking.

Respon siswa terhadap penggunaan Assesment for Learning berbasis Comment Only Marking menunjukkan respon positif berdasarkan hasil dari beberapa indikator yang terdapat pada angket. Siswa menyatakan penggunaan AfL berbasis COM sangat menarik bagi mereka sehingga merasakan feedback yang baik untuk meningkatkan minat dalam pembelajaran biologi di sekolah serta membuat mereka mengetahui kekurangan pengetahuan yang mereka miliki lalu memperbaikinya secara bertahap. Menurut (Jaworski, 2006) mengemukakan bahwa feedback memang membantu siswa dalam memahami kelebihan dan kekurangan pekerjaan serta hasil belajar siswa. Respon positif siswa juga terlihat dari bagaimana siswa menjadi lebih antusias, aktif, tekun, rajin serta belajar lebih sungguh-sungguh karena dari COM yang diberikan guru, menjadikan dorongan yang mempengaruhi siswa untuk meraih nilai yang tinggi.

Untuk mengetahui pengaruh penggunaan Assesment for Learning berbasis Comment Only Marking terhadap hasil belajar kognitif siswa pada materi sistem regulasi dilakukan perhitungan uji normalitas, homogenitas dan uji hipotesis. Uji normalitas dilakukan untuk mengetahui distribusi normal atau tidaknya suatu data.

Tabel 3. Hasil Analisis Uji Normalitas

\begin{tabular}{lccc}
\hline \multicolumn{4}{l}{ Shapiro-Wilk } \\
& Statistic & df & Sig. \\
\hline Pretest & .967 & 36 & .344 \\
Postest & .893 & 36 & .002 \\
\hline
\end{tabular}

Berdasarkan tabel tersebut, diketahui nilai Sig. pretest sebesar 0,344 dan nilai Sig. untuk posttest sebesar 0,002. Karena nilai Sig. untuk keduanya $>0,05$, maka dapat dikatakan bahwa data hasil pretest siswa berdistribusi normal, namun data 
hasil posttest siswa tidak berdistribusi normal. Uji homogenitas dilakukan untuk mengetahui homogen atau tidaknya suatu data.

Tabel 4. Hasil Analisis Uji Homogenitas

\begin{tabular}{lllll}
\hline & Levene Statistic & df1 & df2 & Sig. \\
\hline Nilaiprepost & 3.480 & 1 & 70 & .066 \\
\hline
\end{tabular}

Berdasarkan tabel tersebut diketahui bahwa Sig. adalah sebesar 0,066 0,05, sehingga dapat dikatakan bahwa varians pretest dan siswa adalah sama atau homogen. Tujuan dilakukannya uji hipotesis yaitu untuk membuktikan hipotesis statistic serta hipotesis penelitian yang sebelumnya telah dibuat. Berdasarkan data pretest dan posttest diketahui bahwa data pretest berdistribusi normal sedangkan data posttest tidak berdistribusi normal dan pada uji homogenitas kedua data bersifat homogen. Maka dari itu uji hipotesis dilakukan menggunakan uji wilcoxon (wilcoxon signed rank test).

Tabel 5. Hasil Uji Hipotesis

\begin{tabular}{ll}
\hline Test Statistics $^{\mathfrak{D}}$ & Postest - Pretest \\
\hline$Z$ & $-5.236^{\mathrm{a}}$ \\
Asymp. Sig. (2-tailed) & .000 \\
a. Based on negative ranks. & \\
b. Wilcoxon Signed Ranks Test \\
\hline
\end{tabular}

Berdasarkan hasil perhitungan analisis statistic dengan uji wilcoxon diperoleh Asymp. Sig. (2-tailed) bernilai 0,000. Karena nilai 0,000 lebih kecil dari $<0,05$, maka $\mathrm{H}_{0}$ ditolak dan $\mathrm{H}_{1}$ diterima. Artinya hal tersebut menunjukkan hasil belajar kognitif siswa setelah menggunakan Assesment for Learning berbasis Comment Only Marking lebih baik dibandingkan sebelumnya, sehingga dapat disimpulkan bahwa "ada pengaruh penggunaan Assesment for Learning berbasis Comment Only Marking terhadap hasil belajar kognitif siswa SMA pada materi sistem regulasi manusia".

\section{KESIMPULAN}

Dari penelitian yang telah dilakukan dapat disimpulkan bahwa hasil belajar kognitif siswa termasuk dalam kategori sangat baik dan tuntas setelah dilakukan pembelajaran menggunakan assessment for learning berbasis comment only marking dan sebagian besar siswa merespon positif terhadap penggunaannya. Dengan demikian dapat disimpulkan bahwa terdapat pengaruh dari penggunaan assesment for learning berbasis comment only marking terhadap hasil belajar kognitif siswa SMA pada materi sistem regulasi manusia. Adapun saran bagi peneliti 
lain, sebaiknya penggunaan $A f l$ berbasis COM tidak hanya diterapkan pada satu kelas, namun diterapkan pada beberapa kelas dengan siswa yang memiliki karakter yang lebih banyak dan berbeda, dan COM yang diberikan dapat lebih beragam dan konstruktif.

\section{DAFTAR PUSTAKA}

Anonim. (2003). Undang-Undang Nomor 20 tahun 2003 tentang Sistem Pendidikan Nasional (p. 2).

Anonim. (2013). Peraturan Menteri Pendidikan dan Kebudayaan tahun 2013 Tentang Kriteria Hasil Belajar. In Kementerian Pendidikan dan Kebudayaan.

Anonim. (2017). BSNP Tentang Standar Isi Pendidikan Dasar dan Menengah. In $B S N P$ (pp. 1-20).

Black, P., Harrison, C., Lee, C., Marshall, B., \& Wiliam, D. (2004). Working inside the black box: Assessment for learning in the classroom. Phi Delta Kappan, 86(1), 8-21. https://doi.org/https://doi.org/10.1177/003172170408600105

Bloom, B. S., Engelhart, M. D., Furst, E. J., Hill, W. H., \& Krathwohl, D. R. (1956). Taxonomy of educational objetives: the classification of educational goals: handbook I: cognitive domain. New York, US: D. Mckay.

Council, N. R. (2000). Inquiry and the national science education standards: A guide for teaching and learning. National Academies Press.

Ebrahim, T. (2019). How does differentiation in homework informed by formative assessment influence students' academic performance? University of Oxford.

Erny, E., Haji, S., \& Widada, W. (2017). Pengaruh Pendekatan Saintifik Pada Pembelajaran Matematika Terhadap Kemampuan Pemecahan Masalah Dan Kemampuan Berpikir Tingkat Tinggi Siswa Kelas X Ipa Sma Negeri 1 Kepahiang. Jurnal Pendidikan Matematika Raflesia, 2(1), 1-22. https://doi.org/https://doi.org/10.31186/jpmr.v2i1.3088

Gioka, O. (2010). Assessment for learning in biology lessons. Journal of Biological Education, 41(3), 113-116.

https://doi.org/ttps://doi.org/10.1080/00219266.2007.9656079

Hamalik, O. (2015). Proses Belajar dan Mengajar. In PT Bumi Aksara.

Jaworski, B. (2006). Theory and practice in mathematics teaching development: Critical inquiry as a mode of learning in teaching. Journal of Mathematics Teacher Education, 9(2), 187-211. https://doi.org/https://doi.org/10.1007/s10857-005-1223-z

Kirbani, K. (2013). Pengembangan Model Assessment for Learning (Afl) Melalui Penilaian Teman Sejawat Untuk Pembelajaran Matematika Pada Pokok Bahasan Persamaan Garis Lurus Di Madrasah Tsanawiyah Pondok Pesantren Modern Islam Assalaam Sukoharjo. Jurnal Pembelajaran Matematika, 1(2), 123132.

Koh, J. H. L., Chai, C. S., \& Tsai, C. C. (2010). Examining the technological pedagogical content knowledge of Singapore pre-service teachers with a largescale survey. Journal of Computer Assisted Learning, 26(6), 563-573. https://doi.org/10.1111/j.1365-2729.2010.00372.x

Krathwohl, D. R. (2002). A revision of Bloom's taxonomy: An overview. Theory into Practice, 41(4), 212-218.

https://doi.org/https://doi.org/10.1207/s15430421tip4104_2

O'Mahoney, K., \& Heinz, M. (2016). Using comment only marking in a mathematics classroom in the Republic of Ireland: experience and learning of a student 
teacher. Journal of Teacher Action Research.

Ohlsen, M. T. (2007). Classroom assessment practices of secondary school members of NCTM. American Secondary Education, 4-14. https://doi.org/10.2307/41406094

Sadikin, A. (2018). Penerapan jurnal belajar untuk meningkatkan motivasi belajar mahasiswa pada mata kuliah Dasar-Dasar dan Proses Pembelajaran Biologi. Bioeducation Journal, 2(1), 70-75.

Sadikin, Ali, Aina, M., \& Hakim, N. (2016). Penerapan asesmen berbasis portofolio dan jurnal belajar untuk meningkatkan kemampuan metakognitif dan motivasi belajar mahasiswa pada mata kuliah Perencanaan Pengajaran Biologi. BIODIK, 2(2), 50-61. https://doi.org/https://doi.org/10.22437/bio.v2iNo\%202.4907

Sanjaya, W. (2011). Strategi Pembelajaran Berorientasi Standar Proses Pendidikan. In Kencana Prenada Media Group.

Sugiyono. (2015). Metode penelitian Pendidikan (Pendekatan Kualitatif, Kuantitatif, dan R an D). In Grafindo Persada.

Sulastiyo, S. (2019). Upaya Meningkatkan Aktivitas dan Prestasi Belajar Siswa Pada Bidang Studi Biologi Melalui Penerapan Metode Pembelajaran Kooperatif Tipe STAD. BIODIK, 5(2), 121-130.

https://doi.org/https://doi.org/10.22437/bio.v5i2.7589

Uno, H. B. (2011). Model pembelajaran menciptakan proses belajar mengajar yang kreatif dan efektif. In Bumi Aksara.

Yin, Y., Tomita, M. K., \& Shavelson, R. J. (2014). Using formal embedded formative assessments aligned with a short-term learning progression to promote conceptual change and achievement in science. International Journal of Science Education, 36(4), 531-552. https://doi.org/https://doi.org/10.1080/09500693.2013.787556

Zainul, A. (2008). Asesmen Sumatif dan Asesmen Formatif. In Bahan kuliah Evaluasi Pendidikan IPA di Prodi Pendidikan IPA Pascasarjana UPI.

Ziman, M., Meyer, J., Plastow, K., Fyfe, G., Fyfe, S., Sanders, K., Hill, J., \& Brightwell, R. (2007). Student optimism and appreciation of feedback. Student Engagement. Proceedings of the 16th Annual Teaching and Learning Forum, 30-31. 